\title{
The effect of dolomite amendment on soil organic carbon mineralization is determined by the dolomite size
}

\author{
Hongtao $\mathrm{Wu}^{1,2}$, Jinli $\mathrm{Hu}^{2}$, Muhammad Shaaban ${ }^{3}$, Peng $\mathrm{Xu}^{2}$, Jinsong Zhao ${ }^{2}$ and Ronggui $\mathrm{Hu}^{2^{*}}$ (D)
}

\begin{abstract}
Background: The size of lime material is vital for the efficiency of ameliorating soil acidity, thereby influencing soil biochemical processes. However, the effects of different sized lime material application on soil organic carbon (SOC) mineralization are yet to be elucidated. Therefore, a 35-day incubation experiment was conducted to determine the effects of three particle size fractions ( 0.5 to $0.25,0.25$ to 0.15 , and $<0.15 \mathrm{~mm}$ ) of dolomite on SOC mineralization of two acidic paddy soils.

Results: $\mathrm{CO}_{2}$ emission was increased by 3-7\%, 11-21\%, and 32-49\% for coarse-, medium-, and fine-sized dolomite treatments, respectively, compared to the control in both soils. They also well conformed to a first-order model in all treatments, and the estimated decomposition rate constant was significantly higher in the fine-sized treatment than that of other treatments $(P<0.05)$, indicating that SOC turnover rate was dependent on the dolomite size. The finer particle sizes were characterized with higher efficiencies of modifying soil $\mathrm{pH}$, consequently resulting in higher dissolved organic carbon contents and microbial biomass carbon, eventually leading to higher $\mathrm{CO}_{2}$ emissions.
\end{abstract}

Conclusions: The results demonstrate that the size of dolomite is a key factor in regulating SOC mineralization in acidic paddy soils when dolomite is applied to manipulate soil pH.

Keywords: Dolomite, Particle size, SOC mineralization, Acidic paddy soil

\section{Background}

Soil acidification is known to be a main factor restricting crop growth and yields since acidity influences the physicochemical and biochemical properties of soil (Fageria and Baligar 2008; Shaaban et al. 2017). Approximately $30 \%$ of the world's land surfaces are covered by acidic soils, and $\sim 50 \%$ of global arable soils are acidic (Dai et al. 2017; Kunhikrishnan et al. 2016). In China, approximately 2.04 million $\mathrm{km}^{2}$ of tropical and subtropical soils (mainly paddy soils) may have yield limitation due to low soil pH (Dong et al. 2012). Moreover, the soil pH

\footnotetext{
* Correspondence: rghu@mail.hzau.edu.cn

${ }^{2}$ College of Resources and Environment, Huazhong Agricultural University, Wuhan, China

Full list of author information is available at the end of the article
}

of major croplands decreased noticeably by $0.13-0.8$ units from the 1980s to 2000s (Guo et al. 2010).

Liming is the most widely used agricultural practice for ameliorating soil acidity (Goulding and Blake 1998). The particle size of a lime material is one of the major factors that influences its efficiency of neutralizing soil acidity, because the reaction rate between lime material and $\mathrm{H}^{+}$in the soil is dependent on the specific surface area (Huang et al. 2007). For a given lime material, the finer the particle size, the more rapid rate of dissolution in soil is, and thus, the more effective it is in modifying soil pH (Coleman et al. 1959).

Soil organic carbon (SOC) mineralization is an important process in carbon (C) cycle that is directly linked to soil carbon quality and climate change (Zamanian et al. 2018). Changes in $\mathrm{pH}$, substrate, and nutrient 
availabilities for microbes in the soil after liming can affect SOC mineralization. In general, liming has positive effects on SOC mineralization since it can ameliorate soil acidity and has the potential to increase microbial activity (Adams and Adams 1983; Carmeis Filho et al. 2017). Increase in soil $\mathrm{pH}$ may increase dissolved organic carbon (DOC), which can be rapidly mineralized (Ahmad et al. 2013; Marcelo et al. 2012), and induces a microbial respiratory flush in the first few days following lime application (Fuentes et al. 2006). There are several mechanisms responsible for the enhanced DOC content induced through increased soil $\mathrm{pH}$ : (1) increasing the hydrophilicities of the dissolved organic matter molecules because of enhanced net negative charge with the increase in soil pH (Filep et al. 2003); (2) enhancing the deprotonation of organic substances from hydroxides of iron and aluminum, and clay minerals (Jardine et al. 1989); and (3) increasing the organic matter degradation rate and resulting in more low molecular weight organic matter available for microorganisms (Filep et al. 2003). Liming increases the nutrient availability for microbes, and thus increases SOC mineralization (Baggs et al. 2010; Fageria and Baligar 2008). For example, Shaaban et al. (2017) reported that dolomite addition resulted in high $\mathrm{N}$ mineralization and thus enhanced respiration from acidic soils.

Although the effects of different sizes of lime materials on modifying soil $\mathrm{pH}$ are well understood, few studies have focused their impacts on SOC mineralization via affecting soil $\mathrm{pH}$, substrate, and nutrient availabilities in acidic paddy soils. This question is very important, as different sizes of lime materials may be used in agricultural practices (Álvarez et al. 2009). To address this problem, different size fractions of dolomite were used in the present study. Dolomite was chosen because it is widely used as a good lime material in agriculture in China in the recent years and has the benefit of simultaneously providing $\mathrm{Ca}$ and $\mathrm{Mg}$ during the process of counteracting soil acidity (Radziemska et al. 2018; Shaaban et al. 2015; Wu et al. 2020). The specific objectives of this study were to (1) assess the effects of different sized dolomite on SOC mineralization and (2) assess the effects of dolomite application on SOC turnover rate in acidic paddy soils. We hypothesized that the contents of soil DOC and MBC would increase with the addition of dolomite and the magnitude of the increase would be greater for the finer particle size, therefore resulting in larger SOC mineralization and more soil $\mathrm{CO}_{2}$ emission.

\section{Materials and methods \\ Soils}

Soil samples were collected from the surface layer $(0-20$ $\mathrm{cm})$ of paddy fields located in Qichun $\left(30^{\circ} 09^{\prime} 26.3^{\prime \prime} \mathrm{N}\right.$, $\left.115^{\circ} 22^{\prime} 55.4^{\prime \prime} \mathrm{E}\right)$ and Chibi $\left(29^{\circ} 50^{\prime} 00^{\prime \prime} \mathrm{N}, 114^{\circ} 09^{\prime}\right.$
37" E), Hubei Province, China, with a mid-season rice plus ratooning rice and rapeseed-rice cropping system, respectively. These two areas have a typical subtropical monsoon climate. The soil taken from Qichun (named S1) developed from gneiss, while the soil taken from Chibi (named S2) developed from the Quaternary red earth. Leaves, roots, and stones in the soils were removed by hand prior to soil homogenization. The collected soils were air-dried, ground, and sieved $(2 \mathrm{~mm})$ for the incubation experiment. The physical and chemical properties of the two soils are shown in Table 1.

\section{Fraction of dolomite}

Lumpy dolomite $(3-5 \mathrm{~mm})$, purchased from a mineral powder processing factory in Xingtang County, Hebei Province, China, was ground by a planetary ball mill and then separated into three particle size fractions $(0.5$ to $0.25,0.25$ to 0.15 , and $<0.15 \mathrm{~mm}$ ) with screen meshes. The fraction of dolomite larger than $0.5 \mathrm{~mm}$ was not used in the present study because this fraction of dolomite was proved to be less effective in offsetting soil acidity through a 12-day pre-experiment. The total carbon (TC), calcium oxide, and magnesium oxide contents of the lumpy dolomite are $9.55 \pm 0.30 \%, 30.5 \pm 0.5 \%$, and $22.0 \pm 0.5 \%$, respectively.

\section{Treatments and incubation}

Air-dried soil samples were pre-incubated at $40 \%$ of soil water holding capacity (WHC) by adding sterile deionized water in the dark at $25^{\circ} \mathrm{C}$ for 7 days. Subsequently, aliquots of $250 \mathrm{~g}$ and $200 \mathrm{~g}$ (dry basis, for soil and gas sampling, respectively) of the soils were placed separately in 1-L bottles for further treatment. The incubation experiment of both soil samples was conducted by using four treatments including soils amended with no

Table 1 Selected characteristics of the two paddy soils prior to use in the present study

\begin{tabular}{lll}
\hline Parameters & \multicolumn{2}{l}{ Sampling sites } \\
\cline { 2 - 3 } & Qichun (S1) & Chibi (S2) \\
\hline $\mathrm{pH}\left(1: 2.5 \mathrm{H}_{2} \mathrm{O}\right)$ & $5.19 \pm 0.02$ & $5.57 \pm 0.03$ \\
$\mathrm{TC}(\%)$ & $2.22 \pm 0.04$ & $1.49 \pm 0.01$ \\
$\mathrm{TN}(\%)$ & $0.24 \pm 0.00$ & $0.19 \pm 0.00$ \\
$\mathrm{DOC}\left(\mathrm{mg} \mathrm{kg}^{-1}\right)$ & $70.67 \pm 3.34$ & $84.95 \pm 0.55$ \\
$\mathrm{NH}_{4}{ }^{-}-\mathrm{N}\left(\mathrm{mg} \mathrm{kg}^{-1}\right)$ & $3.29 \pm 1.03$ & $2.49 \pm 0.53$ \\
$\mathrm{NO}_{3}{ }^{-} \mathrm{N}\left(\mathrm{mg} \mathrm{kg}^{-1}\right)$ & $2.12 \pm 0.71$ & $1.64 \pm 0.04$ \\
$\mathrm{WHC}_{(\%)}$ & $61.03 \pm 0.86$ & $42.76 \pm 0.11$ \\
$\mathrm{Clay}(\%)$ & $26.07 \pm 0.21$ & $30.10 \pm 0.28$ \\
Silt (\%) & $55.26 \pm 0.36$ & $67.83 \pm 0.55$ \\
Sand (\%) & $18.66 \pm 0.56$ & $2.07 \pm 0.76$ \\
\hline
\end{tabular}

Data are presented as mean \pm standard deviation $(n=3)$

TC total carbon, $T N$ total nitrogen, DOC dissolved organic carbon, WHC water holding capacity 
dolomite (termed CK), coarse-sized dolomite (0.5-0.25 $\mathrm{mm}$, termed CS), medium-sized dolomite (0.25-0.15 $\mathrm{mm}$, termed MS), and fine-sized dolomite $(<0.15 \mathrm{~mm}$, termed FS). According to the 12-day pre-experiment with the proposal of determining the appropriate application rate of dolomite to increase soil $\mathrm{pH}$ to the target of 6.5 , the rate of $3 \mathrm{~g} \mathrm{~kg}^{-1}$ soil was employed for all dolomite treatments. Then, the soil moisture content was adjusted to $50 \%$ of WHC by adding sterile deionized water. Given that lime material is generally added to acidic soils 2 weeks before rice transplanting when soils are in dry conditions, the moisture content of $50 \%$ WHC was selected. Once the dolomite or sterile deionized water was added, the soil was thoroughly mixed to avoid any heterogeneity. After amendment, each incubation bottle was covered by a plastic film containing several small holes to allow gas exchange and reduce moisture loss. Then, the soils were incubated in the dark at $25^{\circ} \mathrm{C}$ for 35 days in a biochemistry cultivation chamber. Each treatment had three replicates.

\section{Gas sampling and analysis}

Gas sampling was undertaken every day until day 18, and then every 2,3 , and 4 days up to days 24,27 , and 35 during incubation, respectively, to detect the concentration of $\mathrm{CO}_{2}$. The plastic films were removed to allow adequate gas exchange between the interior of the bottles and ambient air for $20 \mathrm{~min}$ prior to sampling. The bottles were then sealed for $1 \mathrm{~h}$ using rubber stoppers. Immediately after closure and after $1 \mathrm{~h}$, two gas samples were withdrawn from the headspace of the incubation bottles, using a gas-tight syringe as described by Shaaban et al. (2017).

The concentrations of the gas samples were analyzed immediately by using a gas chromatography system (GC-Agilent 7890A, USA) installed with a flame ionization detector (FID) for $\mathrm{CO}_{2}$ as described by Shaaban et al. (2017).

\section{Soil sub-sampling and analysis}

Soil sub-samples were collected on days $1,3,5,8,13,20$, 27 , and 35 , and analyzed for $\mathrm{pH}, \mathrm{NH}_{4}{ }^{+}-\mathrm{N}, \mathrm{NO}_{3}{ }^{-}-\mathrm{N}$, dissolved organic carbon (DOC), and microbial biomass carbon (MBC) contents. Sub-samples were also collected on day 0 (after pre-incubated) to identify the starting value of soil $\mathrm{pH}$. Soil $\mathrm{pH}$ was determined in a 1:2.5 (w/v) soil-to-distilled water slurry by a $\mathrm{pH}$ meter (Sartorius, PB-10, Germany). Soil $\mathrm{NH}_{4}{ }^{+}-\mathrm{N}$ and $\mathrm{NO}_{3}{ }^{-}-\mathrm{N}$ were extracted with $1 \mathrm{M} \mathrm{KCl}$ at a $1: 5$ ratio of soil to extractant and detected using the phenol hypochlorite method (Scheiner 1976) and double-wavelength method (at 220 $\mathrm{nm}$ and $275 \mathrm{~nm}$ ) (Lu 2000), respectively. Soil DOC was extracted with deionized water (at a 1:5 ratio of soil to water) and measured using a TOC analyzer (Elementar,
Vario TOC, Germany). Soil DOC content was calculated as the difference of total $\mathrm{C}$ (TC) and inorganic $\mathrm{C}$ contents in the extract. Soil MBC was determined by the modified alcohol-free chloroform fumigation extraction method (Wu et al. 1990). Briefly, soil fumigated with and without chloroform was incubated for $24 \mathrm{~h}$ and then extracted by $0.5 \mathrm{M} \mathrm{K}_{2} \mathrm{SO}_{4}$ (at a 1:5 ratio of soil to solution). The MBC was defined as the difference of organic carbon contents (measured by a TOC analyzer, Elementar, Vario TOC, Germany) between fumigated and nonfumigated samples with a conversion factor of 0.45 .

\section{Data calculation and statistical analysis}

Mean net nitrification rates were calculated as the net changes of soil $\mathrm{NO}_{3}{ }^{-}-\mathrm{N}$ over time. Given that $\mathrm{pH}$ is one of the most important factors affecting nitrification processes in soils, and the changes of $\mathrm{pH}$ among treatments of the two soils were more obvious during the first 20 days than that of 35 days (see the "Results" section), the mean nitrification rates were calculated during the first 20 days of incubation.

$\mathrm{CO}_{2}$ emission fluxes were calculated as the following equation:

$$
\begin{aligned}
F= & \rho \times V / m \times \Delta c / \Delta t \times 273.15 /(T+273.15) \\
& \times f
\end{aligned}
$$

where $F$ is the gas flux (mg $\mathrm{CO}_{2}-\mathrm{C} \mathrm{kg}^{-1}$ dry soil $\left.\mathrm{h}^{-1}\right), \rho$ is the density of gas in standard conditions, $V$ is the volume of the headspace in the bottle $\left(\mathrm{m}^{3}\right)$, $m$ is the weight of the dry soil in the bottle $(\mathrm{kg})$, $\Delta c / \Delta t$ is the change rate of $\mathrm{CO}_{2}$ concentration of the headspace in the bottle during closure time $\left(\mathrm{m}^{3}\right.$ $\left.\mathrm{m}^{-3} \mathrm{~h}^{-1}\right), T$ is the temperature for incubation $\left({ }^{\circ} \mathrm{C}\right)$, and $f$ is the conversion coefficient.

The cumulative $\mathrm{CO}_{2}$ emissions were calculated as the sum of the daily emissions during the incubation by the following equation:

$$
\begin{aligned}
& \text { Cumulative } \mathrm{CO}_{2} \text { emission } \\
& =\sum_{i=1}^{n}\left(F_{i}+F_{i+1}\right) / 2 \times\left(t_{i+1}-t_{i}\right) \times 24
\end{aligned}
$$

where $F$ is the gas flux $\left(\mathrm{mg} \mathrm{CO}_{2}-\mathrm{C} \mathrm{kg}^{-1}\right.$ dry soil h $\left.\mathrm{h}^{-1}\right), i$ is the $i$ th measurement of $\mathrm{CO}_{2},\left(t_{i+1}-t_{i}\right)$ is the days between two adjacent measurements, and $n$ is the number of sampling times.

The cumulative $\mathrm{CO}_{2}$ emissions were fitted with a firstorder model using the Origin statistical package (OriginPro 2017, Origin Lab Corporation, USA). The firstorder model is expressed as follows (Fuentes et al. 2006):

$$
C_{\text {emiss }}=C_{e}+C_{0} \times(1-\exp (-k \times t))
$$


where $C_{\text {emiss }}$ is the cumulative $\mathrm{CO}_{2}$ emission at time $t$ (g CO $2-\mathrm{C} \mathrm{kg}^{-1}$ soil), and $C_{e}$ is the easily mineralizable carbon pool ( $\mathrm{g} \mathrm{CO}_{2}-\mathrm{C} \mathrm{kg}^{-1}$ soil), which is rapidly consumed by microbes during the first few days of incubation (Fuentes et al. 2006). The parameter $C_{e}$ might also have accounted for the initial abiotic flushes of $\mathrm{CO}_{2}$ due to the reaction of soil with dolomite (Kunhikrishnan et al. 2016). The parameter $C_{O}$ is the potentially mineralizable carbon ( $\mathrm{g} \mathrm{CO}_{2}-\mathrm{C} \mathrm{kg}^{-1}$ soil), reflecting soil labile $\mathrm{C}$ pools that accumulated due to inputs and lack of decomposition of $\mathrm{C}$ in the field in history (Costantini et al. 2006); $k$ is the decomposition rate constant $\left(\right.$ day $\left.^{-1}\right)$; and $t$ is the incubation time (day).

The metabolic quotient $\left(q \mathrm{CO}_{2}\right)$ was calculated as $\mathrm{CO}_{2}-\mathrm{C} / \mathrm{MBC}$ to indicate microbial activity.

Prior to analysis, all measured data were checked for normality using a Shapiro-Wilk test, and logtransformed if necessary. One-way analysis of variance (ANOVA) was used to analyze the significance of differences of cumulative $\mathrm{CO}_{2}$ emissions, $q \mathrm{CO}_{2}$, and the estimated parameters in Eq. 3 among the treatments (CK, $\mathrm{CS}, \mathrm{MS}$, and FS). The relationships between soil $\mathrm{pH}$ and DOC and MBC were explored via regression with OriginPro 2017 (Origin Lab Corporation, USA). The relationships between soil $\mathrm{CO}_{2}-\mathrm{C}$ fluxes and soil properties were also explored via regression. The differences of the $\mathrm{cu}-$ mulative $\mathrm{CO}_{2}$ emission and the average of soil MBC between dolomite treatment and the control, termed as $\triangle \mathrm{CO}_{2}$ and $\triangle \mathrm{MBC}$, respectively, were calculated. The relationship between $\triangle \mathrm{CO}_{2}$ and $\triangle \mathrm{MBC}$ was assessed using Pearson's correlation analysis. Two-way repeated measure ANOVA was used to test effects of size of dolomite and sampling time and their interaction on soil $\mathrm{pH}$, $\mathrm{NH}_{4}{ }^{+}-\mathrm{N}, \mathrm{NO}_{3}{ }^{-}-\mathrm{N}, \mathrm{DOC}$, and $\mathrm{MBC}$, as well as $\mathrm{CO}_{2}$ flux.
The path analysis was performed to further reveal the relationships among soil $\mathrm{CO}_{2}$ flux, $\mathrm{pH}, \mathrm{DOC}$, and $\mathrm{MBC}$. All statistical analyses were conducted using IBM SPSS Statistics 20.0 (SPSS, Inc., USA) at 95\% confidence intervals, and all figures were plotted with OriginPro 2017.

\section{Results \\ Soil properties}

The two soils are acidic, while the $\mathrm{pH}$ of $\mathrm{S} 1$ ( $\mathrm{pH}$ 5.19) is lower than that of S2 ( $\mathrm{pH} 5.57$ ) (Table 1). In addition, soil TC and total nitrogen (TN) contents of S1 are higher than those of S2.

Both S1 and S2 with dolomite application exhibited higher $\mathrm{pH}$ than that of the control throughout the study period (Fig. 1a, b). The application of dolomite significantly changed the $\mathrm{pH}$ for both soils $(P<0.001)$, and the dolomite with fine-size was more effective in neutralizing soil acidity than those with course- or medium-size (Fig. 1). In general, soil pH firstly increased and then decreased in both soils during the first 20 days of incubation (Fig. 1). Moreover, the decrease in soil $\mathrm{pH}$ was higher in $\mathrm{S} 2$ than in $\mathrm{S} 1$.

Soil $\mathrm{NH}_{4}{ }^{+}-\mathrm{N}$ content for all treatments in both soils increased in the first 3-8 days of incubation, and it was higher for the fine-sized dolomite treatment than other treatments (Fig. S1a, b). Afterwards, soil $\mathrm{NH}_{4}{ }^{+}-\mathrm{N}$ content began to decline until the end of incubation. Soil $\mathrm{NO}_{3}{ }^{-}-\mathrm{N}$ content in both soils for all treatments increased during the whole incubation, but the increasing pattern differed in soils (Fig. S1c, d). Soil $\mathrm{NO}_{3}{ }^{-}-\mathrm{N}$ content increased exponentially with a lag phase from day 1 to day 8 in $\mathrm{S} 1$, while $\mathrm{NO}_{3}{ }^{-} \mathrm{-N}$ content increased nearly linearly until day 20 and then remained stable until the end of incubation in $\mathrm{S} 2$. In general, soil $\mathrm{NO}_{3}{ }^{-}-\mathrm{N}$ content
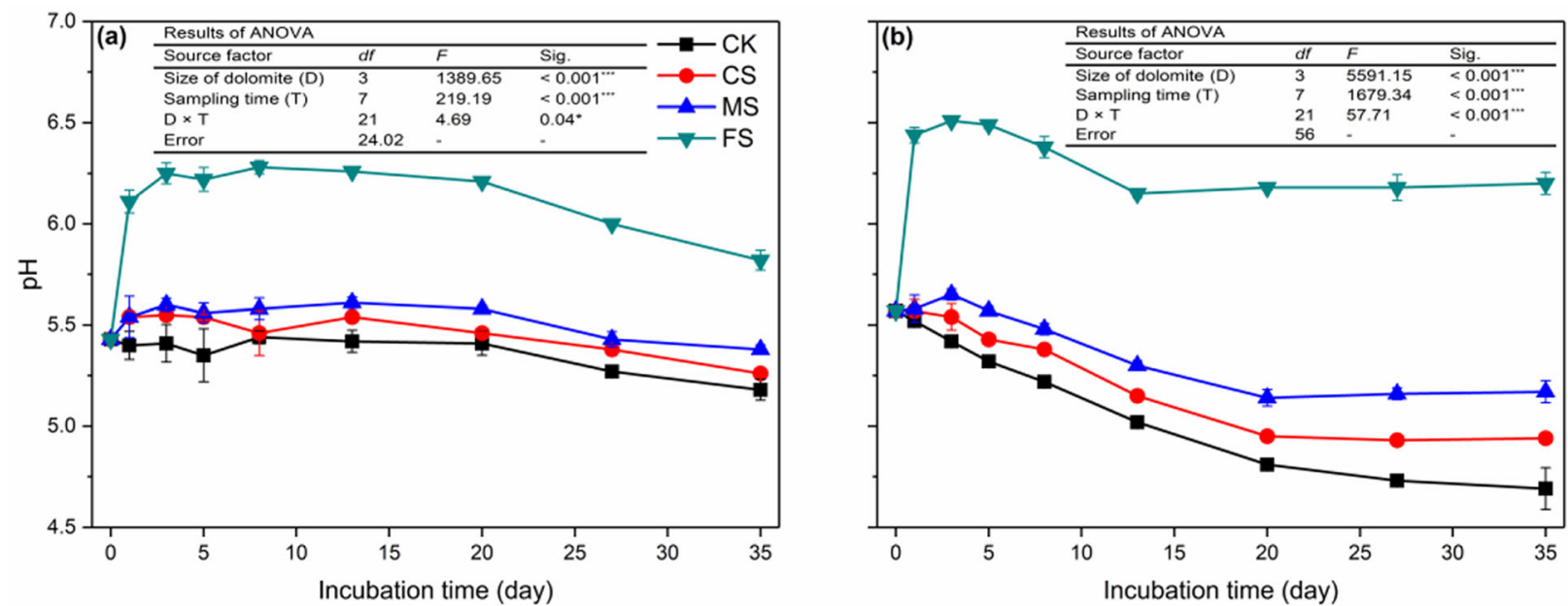

Fig. 1 Dynamics of soil pH in S1 (a) and S2 (b) as affected by different sized dolomite application. Error bars represent standard deviation of the mean values $(n=3)$. CK presents soil without dolomite amendment; CS, MS, and FS present soil with the coarse-, medium-, and fine-sized dolomite amendment, respectively. ${ }^{* *} P<0.001,{ }^{*} P<0.05$ 
was higher for the dolomite treatments than in the control, especially with fine-sized dolomite. The mean net nitrification rates of dolomite treatments in S2 were 2.72-5.99 times higher than those in S1 during the first 20 days of incubation (Table S1).

In general, soil DOC content was increased by dolomite treatments and peaked at $54.21 \pm 2.74,51.63 \pm$ 4.20 , and $70.38 \pm 1.43 \mathrm{mg} \mathrm{kg}^{-1}$ for the coarse-, medium-, and fine-sized dolomite treatments, respectively, in S1 on days 3-5 (Fig. 2a). It also peaked at $36.87 \pm 4.57$, $32.79 \pm 2.42$, and $48.71 \pm 3.08 \mathrm{mg} \mathrm{kg}^{-1}$ for the coarse-, medium-, and fine-sized dolomite treatments, respectively, in S2 on day 3 (Fig. 2b). Afterwards, soil DOC content in both soils decreased gradually until the end of incubation. Moreover, the results of the two-way repeated measure ANOVA showed that DOC contents in both soils were significantly influenced by the particle sizes of dolomite $(P<0.001)$ (Fig. 2a, b). MBC of both soils increased with the application of dolomite and reached the highest values of $250.11 \pm 0.94,223.01 \pm$
15.95 , and $271.67 \pm 15.34 \mathrm{mg} \mathrm{C} \mathrm{kg}{ }^{-1}$ for the coarse-, medium-, and fine-sized dolomite treatments, respectively, on day 1 in S1 and $422.87 \pm 9.33,409.13 \pm 5.68$, and $453.79 \pm 9.04 \mathrm{mg} \mathrm{C} \mathrm{kg}^{-1}$ for the coarse-, medium-, and fine-sized dolomite treatments, respectively, on days 1-3 in S2 (Fig. 2c, d). Then, MBC of both soils decreased during the whole process after the peak time. The results of the two-way repeated measure ANOVA showed that $\mathrm{MBC}$ in both soils was significantly influenced by the particle sizes of dolomite $(P<0.001)$.

\section{Soil $\mathrm{CO}_{2}$ emission}

$\mathrm{CO}_{2}$-C flux of all dolomite treatments in both soils peaked at the initial stage of incubation (on day 1 for the fine-sized dolomite treatment and day 2 for the other two dolomite treatments), known as an initial flush of $\mathrm{CO}_{2}$ evolution (Fig. 3a, b). Afterwards, $\mathrm{CO}_{2}$ - C flux drastically dropped until day 13 and then remained steady until the end of incubation. Moreover, dolomite

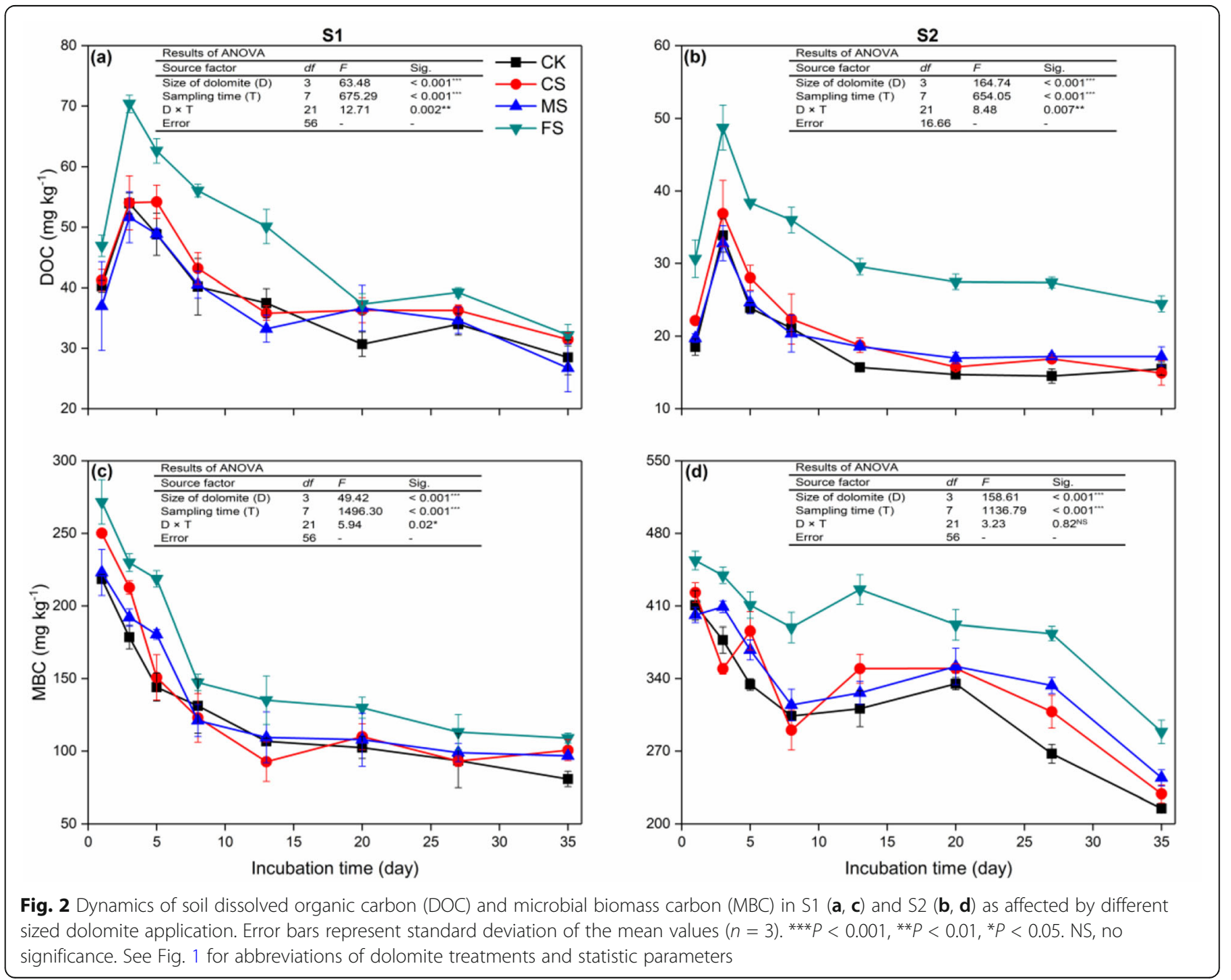



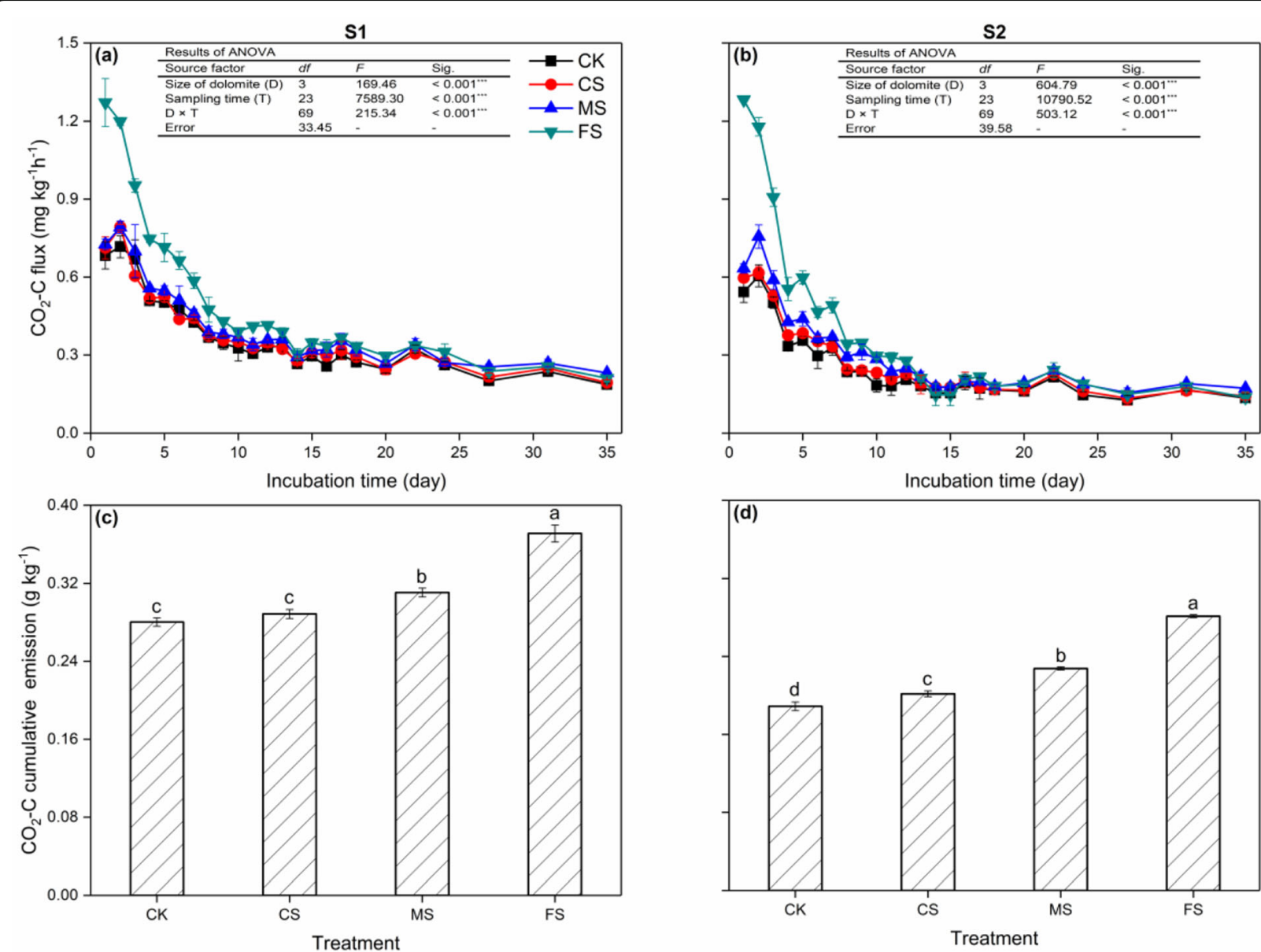

Fig. $3 \mathrm{CO}_{2}-\mathrm{C}$ emission fluxes and cumulative emissions at the end of incubation (day 35) in S1 (a, c) and S2 (b, d) as affected by different sized dolomite application. Error bars represent standard deviation of the mean values $(n=3)$. ${ }^{* * *} P<0.001$. Different letters above bars denote significant differences between treatments (LSD test, $P<0.05$ ). See Fig. 1 for abbreviations of dolomite treatments and statistic parameters

application boosted soil $\mathrm{CO}_{2}$-C flux with the fine-sized dolomite treatment causing the highest rate of soil $\mathrm{CO}_{2}$ emission.

The cumulative $\mathrm{CO}_{2}$ emissions increased by $3 \%, 11 \%$, and $32 \%$, for the coarse-, medium-, and fine-sized dolomite treatments, respectively, compared to the control in S1 (Fig. 3c), whereas those increased by $7 \%, 21 \%$, and $49 \%$, respectively, compared to the control in S2 (Fig. $3 \mathrm{~d})$. One-way ANOVA showed that the cumulative soil $\mathrm{CO}_{2}$ emissions were significantly higher $(P<0.05)$ for the medium- and fine-sized dolomite treatments than for those of the control in S1 (Fig. 3c). The cumulative soil $\mathrm{CO}_{2}$ emissions were significantly higher $(P<0.05)$ for all sizes of dolomite treatments than for the control in S2 (Fig. 3c, d). Moreover, there was a significant difference in the cumulative soil $\mathrm{CO}_{2}$ emissions among dolomite treatments in both soils $(P<0.05)$.

The first-order model fitted the cumulative $\mathrm{CO}_{2}$ emissions well for all treatments (Table 2; Fig. S2a, b). In both soils, the coarse- and medium-sized dolomite treatments did not significantly influence the estimated easily mineralizable $C$ pool $\left(C_{e}\right)$ or the estimated decomposition rate constant $(k)$ compared to the control $(P>$ $0.05)$, while there was a significant increase in the $C_{e}$ and $k$ for the fine-sized dolomite treatments $(P<0.05)$. Only the medium- and fine-sized dolomite treatments significantly enhanced the estimated potentially mineralizable carbon $\left(C_{0}\right)$ compared to the control in $\mathrm{S} 1(P<$ 0.05). In the case of $S 2$, all sizes of dolomite treatments appreciably enhanced $C_{0}(P<0.05)$.

\section{Relationships between soil properties and $\mathrm{CO}_{2}$ emission} The results of regression analysis showed that soil DOC was significantly and positively correlated with soil $\mathrm{pH}$ $(P<0.05)$ (Fig. 4a, b) and MBC $(P<0.05)$ (Fig. 4e, f) in both soils. Soil MBC was also significantly and positively correlated with soil $\mathrm{pH}$ in both soils $(P<0.05)$ (Fig. 4c, d). In both soils, $\mathrm{CO}_{2}$ emissions had significantly positive correlations with soil $\mathrm{pH}(P<0.05)$ (Fig. 5a, b), DOC ( $P$ $<0.05$ ) (Fig. 5c, d), and MBC $(P<0.05)$ (Fig. 5e, f). The 
Table 2 Estimated parameters for measuring the easily mineralizable $C$ pool $\left(C_{e}\right)$, potentially mineralizable carbon $\left(C_{0}\right)$ and decomposition rate constant ( $k)$, and determination coefficients $\left(R^{2}\right)$ using the first-order model of the cumulative soil $\mathrm{CO}_{2}$ emission

\begin{tabular}{lllll}
\hline Treatments & $\boldsymbol{C}_{\boldsymbol{e}}\left(\mathbf{g} \mathbf{~ k g}^{-\mathbf{1}}\right)$ & $\boldsymbol{C}_{\boldsymbol{o}}\left(\mathbf{g} \mathbf{~ k g}^{-\mathbf{1}}\right)$ & $\boldsymbol{k}\left(\mathbf{d a y}^{\mathbf{- 1}}\right)$ & $\boldsymbol{R}^{\mathbf{2}}$ \\
\hline S1 & & & & \\
CK & $0.013 \pm 0.002 \mathrm{~b}$ & $0.372 \pm 0.010 \mathrm{c}$ & $0.035 \pm 0.002 \mathrm{~b}$ & 0.995 \\
CS & $0.014 \pm 0.002 \mathrm{~b}$ & $0.392 \pm 0.011 \mathrm{bc}$ & $0.033 \pm 0.002 \mathrm{~b}$ & 0.996 \\
MS & $0.014 \pm 0.002 \mathrm{~b}$ & $0.433 \pm 0.015 \mathrm{a}$ & $0.032 \pm 0.002 \mathrm{~b}$ & 0.995 \\
FS & $0.029 \pm 0.003 \mathrm{a}$ & $0.405 \pm 0.009 \mathrm{~b}$ & $0.049 \pm 0.002 \mathrm{a}$ & 0.992 \\
S2 & & & & \\
CK & $0.014 \pm 0.002 \mathrm{~b}$ & $0.222 \pm 0.008 \mathrm{c}$ & $0.041 \pm 0.003 \mathrm{~b}$ & 0.986 \\
CS & $0.014 \pm 0.002 \mathrm{~b}$ & $0.232 \pm 0.006 \mathrm{~b}$ & $0.043 \pm 0.002 \mathrm{~b}$ & 0.992 \\
MS & $0.015 \pm 0.002 \mathrm{~b}$ & $0.258 \pm 0.006 \mathrm{a}$ & $0.045 \pm 0.002 \mathrm{~b}$ & 0.992 \\
FS & $0.031 \pm 0.003 \mathrm{a}$ & $0.255 \pm 0.005 \mathrm{a}$ & $0.073 \pm 0.004 \mathrm{a}$ & 0.985 \\
\hline
\end{tabular}

Values are presented as mean \pm standard deviation of estimated parameters $(n=3)$

CK presents soil without dolomite amendment; CS, MS, and FS present soil with the coarse-, medium-, and fine-sized dolomite amendment, respectively Different letters in a column indicate significant differences between treatments in a single soil (LSD test, $P<0.05$ )

results of the path analysis further indicated that soil $\mathrm{pH}$ had apparent and direct effect on DOC and MBC in soil S2, but only on DOC in soil S1 (Fig. 6). Soil DOC had significant and direct effect on MBC in soil S1, but its effect was weak in soil S2. Furthermore, soil MBC rather than DOC had apparent and direct effect on soil $\mathrm{CO}_{2}$ flux in both soils.

The results of Pearson's correlation analysis showed that $\triangle \mathrm{CO}_{2}$ also positively correlated with soil $\triangle \mathrm{MBC}$ in both soils $(r=0.972, P=0.028$, and $r=0.986, P=0.014$, for S1 and S2, respectively).

\section{Discussion}

\section{Effect of dolomite particle size on soil pH}

In the present study, dolomite addition increased soil $\mathrm{pH}$ in acidic soils as compared with the control, and the fine-sized dolomite treatment was more effective at neutralizing soil acidity (Fig. 1a, b). Similar findings have been reported by previous studies (Jones 2016; Tjv and Lewis 1994), which all indicated that increasing the fineness of lime materials increased their efficiency of counteracting soil acidity. The scenario of increase in soil $\mathrm{pH}$ caused by the fine-sized dolomite addition was due to its greater specific surface area and more rapid dissolution rate in the soil (Huang et al. 2007; Jones 2016).

In general, $\mathrm{pH}$ of the dolomite-amended soil firstly increased and then decreased in both soils during the first 20 days of incubation (Fig. 1a, b). The result was consistent with previous studies (Álvarez et al. 2009; Li et al. 2018). This decrease in soil $\mathrm{pH}$ might be attributed to nitrification, in which 2 mole protons are released per mole $\mathrm{NH}_{4}{ }^{+}$oxidized to $\mathrm{NO}_{3}{ }^{-}$(Haynes and Swift 1988). As exhibited in the present study, $\mathrm{NO}_{3}{ }^{-}-\mathrm{N}$ content increased during the incubation for all treatments in both soils (Fig. S1c, d), suggesting that nitrification occurred. The results also showed that the mean net nitrification rates of dolomite treatments in S2 were 2.72-5.99 times higher than those in S1 during the first 20 days of incubation (Table S1), probably resulting in a greater decrease in soil $\mathrm{pH}$ in $\mathrm{S} 2$ than in S1 (Fig. 1a, b). Differences in nitrification rates from the two soils could be due to different soil properties. Taking soil initial $\mathrm{pH}$ for example, since it was lower in S1 than S2 (Table 1), the acid-sensitive nitrifiers rather than acid-tolerant nitrifiers in S1 may not adapt to the increasing $\mathrm{pH}$ circumstance at the initial incubation (Cheng et al. 2013; Nugroho et al. 2007), leading to a lag effect of $\mathrm{pH}$ stimulation of nitrification and lower nitrification rate than S2 (Table S1).

\section{Effect of dolomite particle size on SOC mineralization}

As mentioned above in the "Materials and methods" section, besides microbial-mediated $\mathrm{CO}_{2}$ emission, limederived $\mathrm{CO}_{2}$ evolution may occur after liming. However, we proposed that there was no abiotic $\mathrm{CO}_{2}$ emission or it could be ignored in the present study. This was supported by the following three aspects. Firstly, the results of regression analysis showed that there was a significantly positive correlation between $\mathrm{CO}_{2}$ emission flux and soil MBC (Fig. 5e, f), the results of Pearson's correlation analysis showed that $\Delta \mathrm{CO}_{2}$ was also positively correlated with soil $\triangle \mathrm{MBC}$ in both soils $(r=0.972, P=$ 0.028 , and $r=0.986, P=0.014$, for S1 and S2, respectively), and the results of path analysis showed that soil $\mathrm{pH}$ had no direct effect on $\mathrm{CO}_{2}$ emission flux, confirming that microorganisms played a major role in $\mathrm{CO}_{2}$ emissions. Secondly, supposing that all $\mathrm{H}^{+}$consumed during the increase of $\mathrm{pH}$ was used for dolomite dissolution and abiotic $\mathrm{CO}_{2}$ production, we calculated that only $0.57-1.57 \%$ and $0.26-1.09 \%$ of total $\mathrm{CO}_{2}$ emission were attributed to abiotic $\mathrm{CO}_{2}$ production in $\mathrm{S} 1$ and $\mathrm{S} 2$, respectively. Therefore, the quantities of abiotic $\mathrm{CO}_{2} \mathrm{can}$ be ignored. Finally, $\mathrm{CO}_{2}$ emission occurs from the reaction between $\mathrm{H}^{+}$and carbonate minerals when soil $\mathrm{pH}<$ 5 (Hamilton et al. 2007), whereas, in the present study, soil $\mathrm{pH}$ of all dolomite treatments in both soils was above 5 during the incubation, except that $\mathrm{pH}$ of the coarse-sized dolomite treatment in S2 was slightly lower than 5 during days $20-35$ of incubation (4.93-4.95), when $\mathrm{CO}_{2}$ flux was fairly low and steady. Overall, the major $\mathrm{CO}_{2}$ emission resulted from SOC mineralization instead of abiotic $\mathrm{CO}_{2}$ evolution.

The present study showed that soil $\mathrm{CO}_{2}$ emissions were increased by dolomite application in both soils (Fig. 3a, b), indicating that liming prompted SOC 

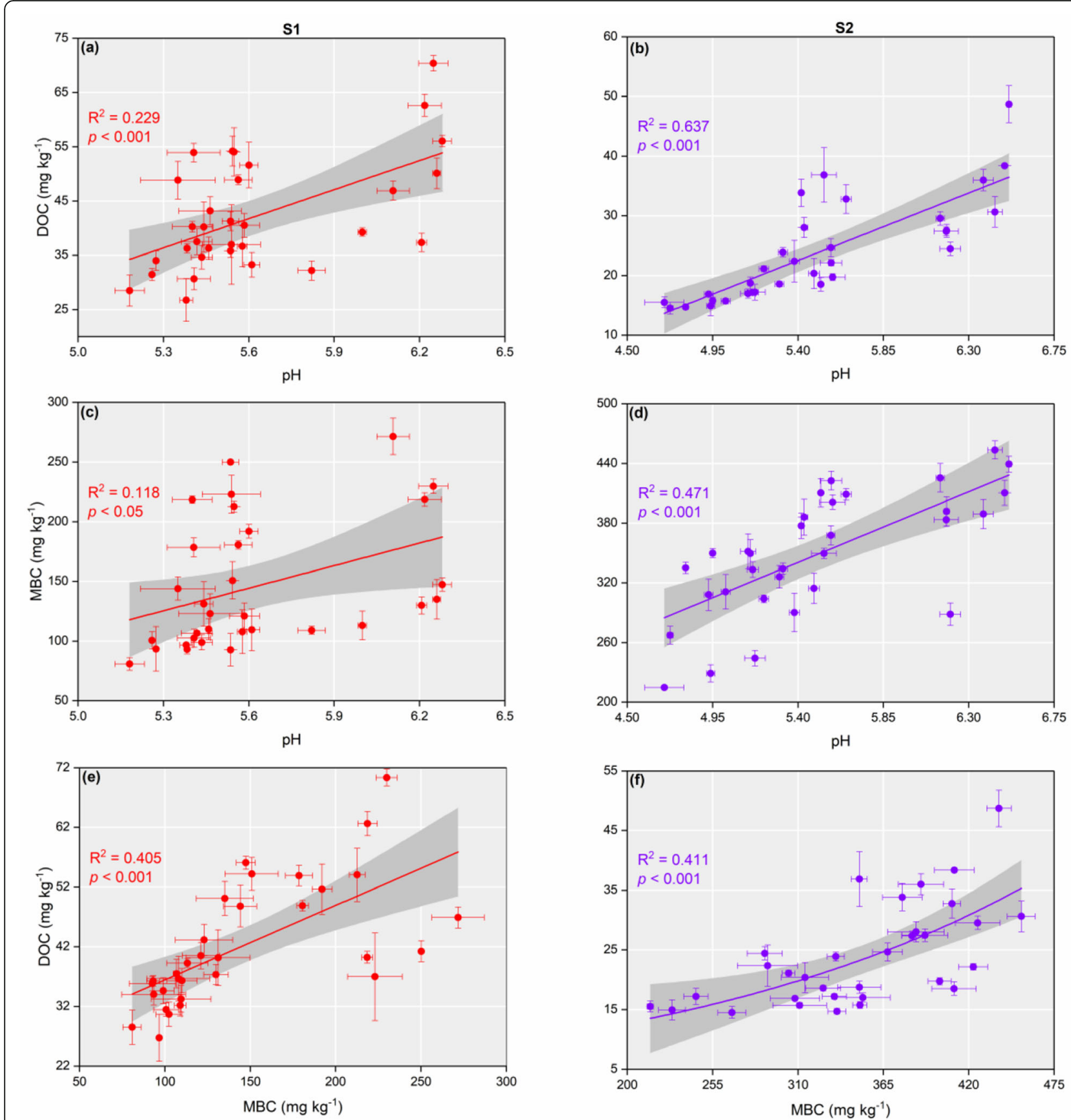

Fig. 4 Relationships among soil pH, dissolved organic carbon (DOC), and microbial biomass carbon (MBC) in S1 (a, c, e) and S2 (b, d, f). Shaded bands represent 95\% pointwise confidence intervals. Error bars represent standard deviation of the variables $(n=3)$

mineralization and $\mathrm{CO}_{2}-\mathrm{C}$ loss. This result is in line with many previous laboratory studies (Bertrand et al. 2007; Lochon et al. 2018; Persson et al. 1989; Xiao et al. 2018) as well as field experiments in cropland soils (Chan and Heenan 1999), forest soils (Nilsson et al. 2001; Persson et al. 1995), and grassland soils (Fornara et al. 2011; Mijangos et al. 2010). A possible explanation for the positive effect of dolomite application on the SOC stock loss is that short-term dolomite treatment resulted in higher biological activity via increasing soil pH (Holland et al. 2017). Soil microbial activity is controlled by the physicochemical and biochemical properties of soil, especially soil $\mathrm{pH}$ which is one of the dominant factors (Adams and Adams 1983; Higashida and Takao 1986; Xiao et al. 2018). Liming increased microbial activity in soils (Andersson and Nilsson 2001; Paradelo et al. 2015) 

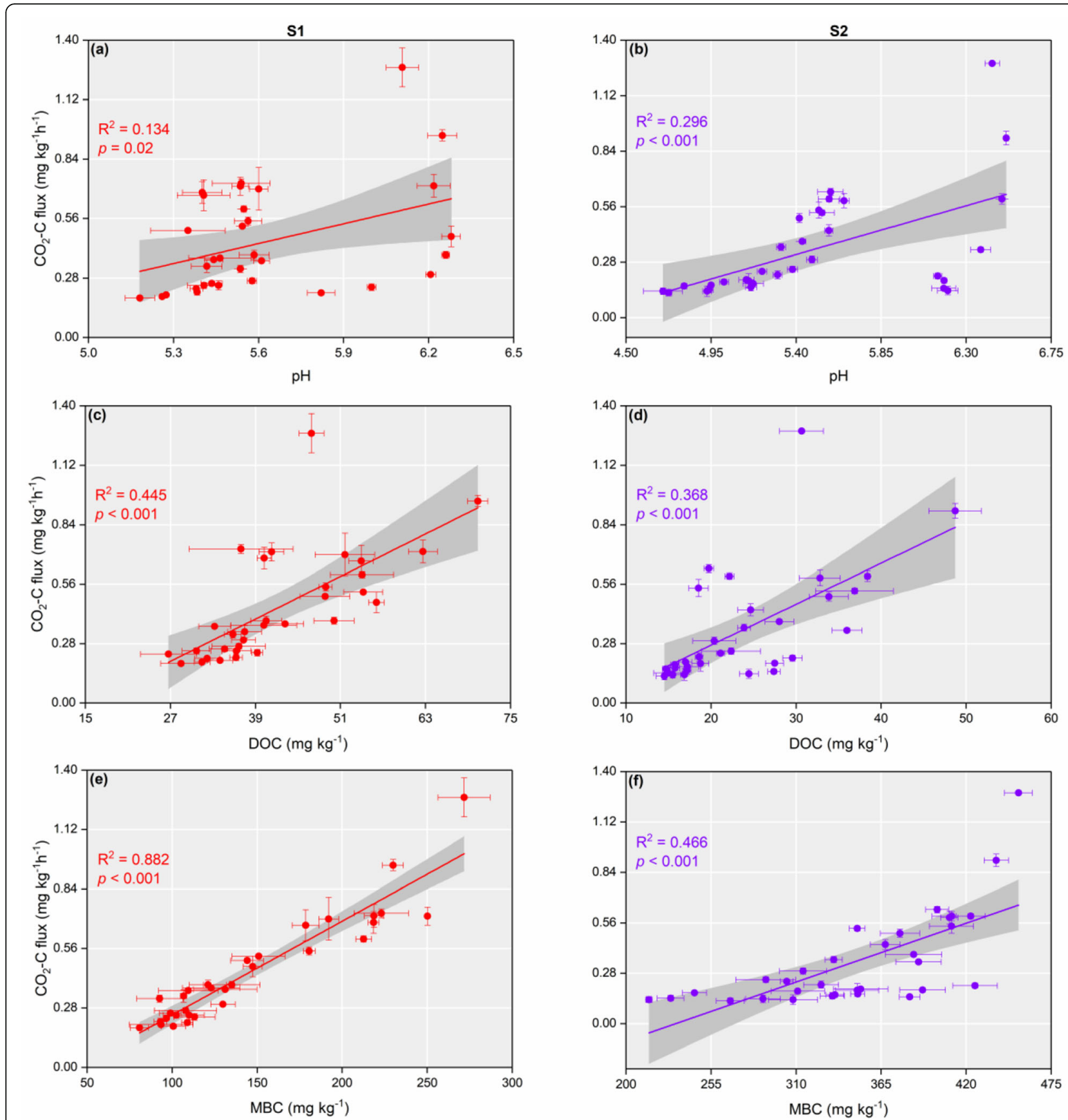

Fig. 5 Relationships between $\mathrm{CO}_{2}$ emission flux and soil pH, dissolved organic carbon (DOC), and microbial biomass carbon (MBC) in $\mathrm{S} 1$ (a, c, e) and S2 (b, d, f). Shaded bands represent 95\% pointwise confidence intervals. Error bars represent standard deviation of the variables $(n=3)$

either by facilitating release of easily available $\mathrm{C}$ (e.g., DOC) to microbial consumption (Shaaban et al. 2017; Zelles et al. 1990) or by offsetting soil acidity and favoring microflora with a smaller C-use efficiency, thus resulting in more evolution of $\mathrm{CO}_{2}$ in soils (Holland et al. 2017). Our results showed that soil MBC was positively correlated with both soil DOC content and $\mathrm{CO}_{2}-\mathrm{C}$ flux (Figs. 4e, $\mathrm{f}$ and $5 \mathrm{e}, \mathrm{f}$ ), suggesting that $\mathrm{MBC}$ could be an indicator of microbial activity (Mendham et al. 2002). In addition, the metabolic quotient $\left(q \mathrm{CO}_{2}\right)$, as an indicator of microbial activity, was higher from soils treated with fine-sized dolomite than that with other treatments (Fig. S3). Moreover, both soil DOC and MBC contents, which were increased with the application of dolomite (Fig. 2a-d), were positively correlated with soil pH (Fig. $4 a-d)$. These results provided evidence that both soil 


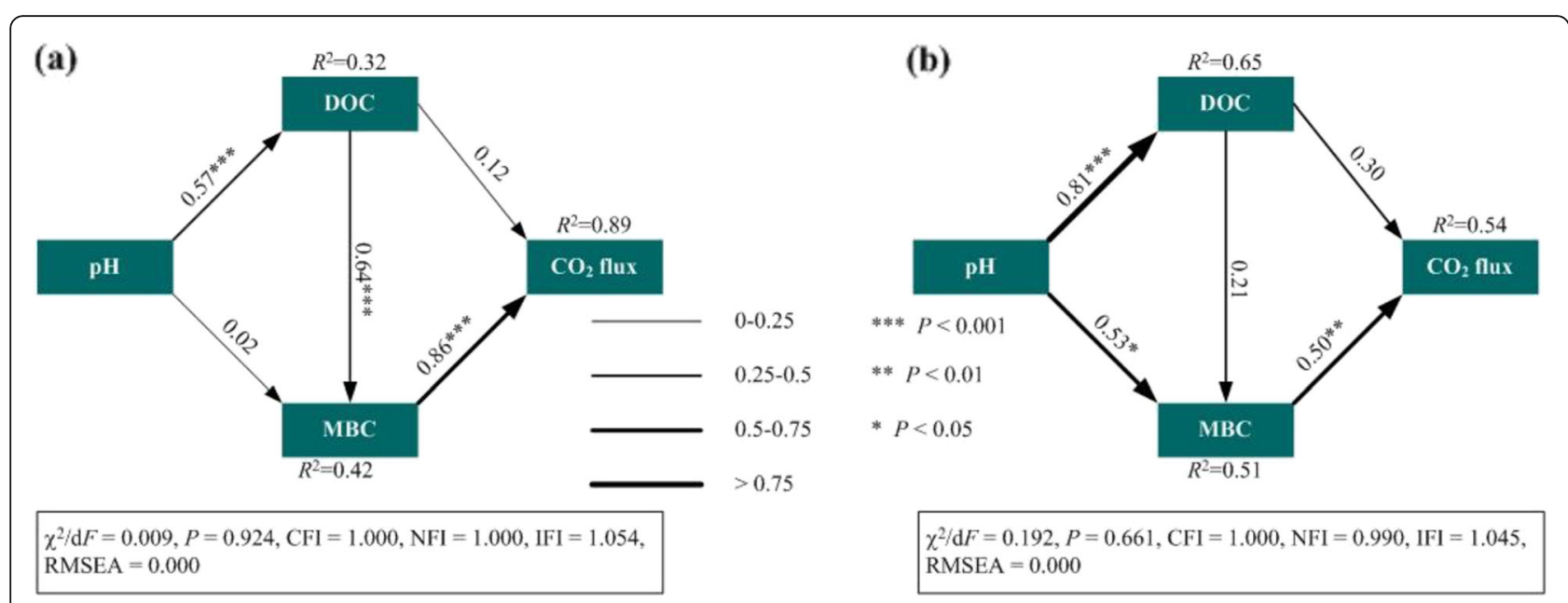

Fig. 6 Results of the path analysis showing the correlations among $\mathrm{CO}_{2}$ fluxes and pH, DOC and MBC in soil S1 (a) and S2 (b)

microbial activity and easily available $\mathrm{C}$ substrate increased after the application of dolomite.

What is really noteworthy was that there was a significant difference in the cumulative $\mathrm{CO}_{2}$ emissions between dolomite treatments in both soils (Fig. 3c, d), and higher cumulative $\mathrm{CO}_{2}$ emission was observed from the finer particle sizes of dolomite treatment, suggesting that the magnitude of SOC mineralization was significantly affected by the particle size of dolomite. The possible reason for the results was that soil $\mathrm{pH}$ was significantly influenced by the particle sizes of dolomite and the finer particle sizes of dolomite treatment led to a higher increase in soil pH (Fig. 1a, b), consequently resulting in greater availability of $\mathrm{C}$ substrates for microorganisms (Fig. 2a, b) and higher microbial activity (indicated by $\mathrm{MBC}$ and $q \mathrm{CO}_{2}$, Figs. 2c, d and S3), eventually leading to a significantly higher SOC mineralization (Fig. 3c, d).

\section{Effect of dolomite particle size on SOC turnover rate}

The decomposition rate constant $(k)$ is usually used as an indicator of the turnover rate of SOC (Curtin et al. 1998; Fuentes et al. 2006). The fine-sized rather than coarse- and medium-sized dolomite treatment resulted in a significant increase in the value of $k$ in both soils (Table 2), suggesting that the SOC turnover rate was dependent on the particle size of dolomite. The decomposition rate constant $(k)$ was regulated by environmental factors and soil conditions (Campbell et al. 1994). Previous studies indicated that liming could increase the turnover rate of soil organic matter due to increase in soil $\mathrm{pH}$ thus facilitating microbial activity (Carmeis Filho et al. 2017; Lochon et al. 2018). Soil pH is considered as a key factor governing the microbial turnover of organic carbon (Bertrand et al. 2007; Xiao et al. 2018). In addition, the value of $k$ should be reduced in conditions with suboptimal $\mathrm{pH}$ values (Curtin et al. 1998). As mentioned above, although soil $\mathrm{pH}$ of both $\mathrm{S} 1$ and $\mathrm{S} 2$ was significantly influenced by the particle sizes of dolomite, the fine-sized dolomite treatment was more effective at neutralizing soil acidity than other two dolomite treatments. Therefore, the probable reason for the significant positive effect of the fine-sized dolomite was that soil $\mathrm{pH}$ was increased enough to affect the SOC decomposition rates by the fine-sized dolomite treatment than other two sizes did.

\section{Conclusion}

The results indicated that dolomite application increased SOC mineralization via enhancing DOC production and stimulating microbial growth and activity, which resulted from the increase in soil $\mathrm{pH}$. Moreover, the effect was greater for the finer particle size, suggesting that the particle size of lime material has the role in regulating the SOC mineralization and $\mathrm{CO}_{2}-\mathrm{C}$ loss in acidic soils. The results suggested that the particle size of lime material influences not only the soil $\mathrm{pH}$, substrate availability, and microbial activity, but also the soil carbon stock as well as soil fertility in acidic paddy soils. Therefore, the fineness of lime material should be appropriately considered to ameliorate soil acidity when addressing SOC budget.

\section{Supplementary Information}

The online version contains supplementary material available at https://doi. org/10.1186/s13717-020-00278-x.

Additional file 1: Fig. S1. Dynamics of soil $\mathrm{NH}_{4}{ }^{+}-\mathrm{N}$ and $\mathrm{NO}_{3}{ }^{-}-\mathrm{N}$ in $\mathrm{S} 1$ $(a, c)$ and $\mathbf{S} 2(b, d)$ as affected by different sized dolomite application. Error bars represent standard deviation of the mean values $(n=3)$. CK presents soil without dolomite amendment; CS, MS, and FS presents soil with the coarse-, medium-, and fine-sized dolomite amendment, respectively. ${ }^{* *} P<0.001,{ }^{* *} P<0.01,{ }^{*} P<0.05$, ${ }^{\text {NS }}$ no significance. Fig. S2. Changes in the cumulative soil $\mathrm{CO}_{2}-\mathrm{C}$ emission and decomposition 
kinetic curve for all treatments in S1 (a) and S2 (b). The curves were modeled by $C_{\text {emiss }}=C_{e}+C_{0} \times(1-\exp (-k \times t))$. See Fig. S1 for abbreviations of dolomite treatments. Fig. S3. Dynamics of soil metabolic quotient $\left(q \mathrm{CO}_{2}\right)$ in S1 (a) and S2 (b) as affected by different sized dolomite application. Different letters above bars denote significant differences between treatments (LSD test, $P<0.05$ ). See Fig. S1 for abbreviations of dolomite treatments and statistic parameters. Table S1. Mean net nitrification rates (mg N kg${ }^{-1} \mathrm{~d}^{-1}$ ) of two soils during the first 20 days of incubation.

\section{Abbreviations}

ANOVA: Analysis of variance; C: Carbon; DOC: Dissolved organic carbon: FID: Flame ionization detector; MBC: Microbial biomass carbon; SOC: Soil organic carbon; TC: Total carbon; TN: Total nitrogen; WHC: Water holding capacity

\section{Acknowledgements}

The authors sincerely appreciate the coworkers and students of Hubei Normal University for their excellent assistance with soil sampling in the field.

\section{Authors' contributions}

$\mathrm{HW}$ and $\mathrm{RH}$ designed the experiment. HW and $\mathrm{JH}$ performed the experiment, processed the data, and performed the statistical analyses. The manuscript was drafted by HW, JH, MS, and PX which was finalized by HW, $\mathrm{JZ}$, and RH. All authors have read and approved the final version of manuscript.

\section{Funding}

National Key Research and Development Program of China (2017YFD0800102): Research Project of Hubei Provincial Department of Education (D20202503).

\section{Availability of data and materials}

Not applicable.

\section{Ethics approval and consent to participate}

Not applicable.

\section{Consent for publication}

Not applicable.

\section{Competing interests}

The authors declare that they have no competing interests.

\section{Author details}

'College of Urban and Environmental Sciences, Hubei Normal University, Huangshi, China. ${ }^{2}$ College of Resources and Environment, Huazhong Agricultural University, Wuhan, China. ${ }^{3}$ Department of Soil Science, Faculty of Agricultural Sciences and Technology, Bahauddin Zakariya University, Multan, Pakistan.

Received: 24 January 2020 Accepted: 4 December 2020

Published online: 07 January 2021

\section{References}

Adams TM, Adams SN (1983) The effects of liming and soil pH on carbon and nitrogen contained in the soil biomass. J Agr Sci 101:553-558. https://doi. org/10.1017/S0021859600038570

Ahmad W, Singh B, Dijkstra FA, Dalal RC (2013) Inorganic and organic carbon dynamics in a limed acid soil are mediated by plants. Soil Biol Biochem 57 549-555. https://doi.org/10.1016/j.soilbio.2012.10.013

Álvarez E, Viadé A, Fernández ML (2009) Effect of liming with different sized limestone on the forms of aluminium in a Galician soil (NW Spain). Geoderma 152:1-8. https://doi.org/10.1016/j.geoderma.2009.04.011

Andersson S, Nilsson SI (2001) Influence of pH and temperature on microbial activity, substrate availability of soil-solution bacteria and leaching of dissolved organic carbon in a mor humus. Soil Biol Biochem 33:1181-1191. https://doi.org/10.1016/50038-0717(01)00022-0
Baggs EM, Smales CL, Bateman EJ (2010) Changing pH shifts the microbial source as well as the magnitude of $\mathrm{N}_{2} \mathrm{O}$ emission from soil. Biol Fertil Soils 46:793805. https://doi.org/10.1007/s00374-010-0484-6

Bertrand I, Delfosse O, Mary B (2007) Carbon and nitrogen mineralization in acidic, limed and calcareous agricultural soils: apparent and actual effects. Soil Biol Biochem 39:276-288. https://doi.org/10.1016/j.soilbio.2006.07.016

Campbell C, Jame YW, Akinremi O, Beckie HJ (1994) Evaluating potential nitrogen mineralization for predicting fertilizer nitrogen requirements of long-term field experiments. In: Havlin JL, Jacobson JS (eds) Soil testing: prospects for improving nutrient recommendations. Soil Science Society of America, Madison, pp 81-100

Carmeis Filho ACA, Penn CJ, Crusciol CAC, Calonego JC (2017) Lime and phosphogypsum impacts on soil organic matter pools in a tropical Oxisol under long-term no-till conditions. Agric Ecosyst Environ 241:11-23. https:// doi.org/10.1016/j.agee.2017.02.027

Chan KY, Heenan DP (1999) Lime-induced loss of soil organic carbon and effect on aggregate stability. Soil Sci Soc Am J 63:1841-1844. https://doi.org/10. 2136/sssaj1999.6361841x

Cheng Y, Wang J, Mary B, Zhang JB, Cai ZC, Chang SX (2013) Soil pH has contrasting effects on gross and net nitrogen mineralizations in adjacent forest and grassland soils in central Alberta, Canada. Soil Biol Biochem 57: 848-857. https://doi.org/10.1016/j.soilbio.2012.08.021

Coleman NT, Kamprath EJ, Weed SB (1959) Liming. Adv Agron 10:474-522. https://doi.org/10.1016/S0065-2113(08)60073-5

Costantini A, De-Polli H, Galarza C, Rossiello RP, Romaniuk R (2006) Total and mineralizable soil carbon as affected by tillage in the Argentinean Pampas. Soil Tillage Res 88:274-278. https://doi.org/10.1016/j.still.2005.06.016

Curtin D, Campbell CA, Jalil A (1998) Effects of acidity on mineralization: pHdependence of organic matter mineralization in weakly acidic soils. Soil Biol Biochem 30:57-64. https://doi.org/10.1016/S0038-0717(97)00094-1

Dai Z, Zhang X, Tang C, Muhammad N, Wu J, Brookes PC, Xu J (2017) Potential role of biochars in decreasing soil acidification - a critical review. Sci Total Environ 581-582:601-611. https://doi.org/10.1016/j.scitotenv.2016.12.169

Dong W, Zhang X, Wang H, Dai X, Sun X, Qiu W, Yang F (2012) Effect of different fertilizer application on the soil fertility of paddy soils in red soil region of southern China. PLoS One 7:e44504. https://doi.org/10.1371/journal.pone. 0044504

Fageria NK, Baligar VC (2008) Ameliorating soil acidity of tropical oxisols by liming for sustainable crop production. Adv Agron 99:345-399. https://doi. org/10.1016/S0065-2113(08)00407-0

Filep T, Kincses I, Nagy P (2003) Dissolved organic carbon (DOC) and dissolved organic nitrogen (DON) content of an arenosol as affected by liming in a pot experiment. Arch Agron Soil Sci 49:111-117. https://doi.org/10.1080/ 0365034031000079793

Fornara DA et al (2011) Increases in soil organic carbon sequestration can reduce the global warming potential of long-term liming to permanent grassland. Global Change Biol 17:1925-1934. https://doi.org/10.1111/j.1365-2486.2010. 02328.x

Fuentes JP, Bezdicek DF, Flury M, Albrecht S, Smith JL (2006) Microbial activity affected by lime in a long-term no-till soil. Soil Tillage Res 88:123-131. https://doi.org/10.1016/j.still.2005.05.001

Goulding KWT, Blake L (1998) Land use, liming and the mobilization of potentially toxic metals. Agric Ecosyst Environ 67:135-144. https://doi.org/10. 1016/s0167-8809(97)00111-4

Guo JH et al (2010) Significant acidification in major Chinese croplands. Science 327:1008-1010. https://doi.org/10.1126/science.1182570

Hamilton SK, Kurzman AL, Arango C, Jin L, Robertson GP (2007) Evidence for carbon sequestration by agricultural liming. Global Biogeochem Cycles 21: GB2021. https://doi.org/10.1029/2006GB002738

Haynes RJ, Swift RS (1988) Effect of lime and phosphate additions on changes in enzyme activities, microbial biomass and levels of extractable nitrogen, sulphur and phosphorous in an acid soil. Biol Fertil Soils 6:153-158. https:// doi.org/10.1007/BF00257666

Higashida S, Takao K (1986) Relations between soil microbial activity and soil properties in grassland. J Soil Sci Plant Nutr 32:587-597. https://doi.org/10. 1080/00380768.1986.10557540

Holland JE et al (2017) Liming impacts on soils, crops and biodiversity in the UK: a review. Sci Total Environ 610-611:316-332. https://doi.org/10.1016/j. scitotenv.2017.08.020

Huang J, Fisher PR, Argo WR (2007) Container substrate-pH response to differing limestone type and particle size. HortScience 42:1268-1273 
Jardine PM, Mccarthy JF, Weber NL (1989) Mechanisms of dissolved organic carbon adsorption on soil. Soil Sci Soc Am J 53:1378-1385. https://doi.org/10. 2136/sssaj1989.03615995005300050013x

Jones JD (2016) Influence of source and particle size on agricultural limestone efficiency at increasing soil pH. Master Thesis, lowa State University.

Kunhikrishnan A et al (2016) Functional relationships of soil acidification, liming and greenhouse gas flux. Adv Agron 139:1-71. https://doi.org/10.1016/bs. agron.2016.05.001

Li Z, Wei B, Wang X, Zhang Y, Zhang A (2018) Response of soil organic carbon fractions and $\mathrm{CO}_{2}$ emissions to exogenous composted manure and calcium carbonate. J Soils Sediments 18:1832-1843. https://doi.org/10.1007/s11368018-1946-y

Lochon I, Carrère P, Revaillot S, Bloor JMG (2018) Interactive effects of liming and nitrogen management on carbon mineralization in grassland soils. Appl Soil Ecol 130:143-148. https://doi.org/10.1016/j.apsoil.2018.06.010

Lu R (2000) Analysis methods on soil agro-chemistry. Chinese Agricultural Science and Technology Press, Beijing

Marcelo A, Eduardo Corá J, La Scala JN (2012) Influence of liming on residual soil respiration and chemical properties in a tropical no-tillage system. Rev Bras Cienc Solo 36:45-50. https://doi.org/10.1590/S0100-06832012000100005

Mendham DS, Sankaran KV, O'Connell AM, Grove TS (2002) Eucalyptus globulus harvest residue management effects on soil carbon and microbial biomass at 1 and 5 years after plantation establishment. Soil Biol Biochem 34:1903-1912. https://doi.org/10.1016/S0038-0717(02)00205-5

Mijangos I, Albizu I, Epelde L, Amezaga I, Mendarte S, Garbisu C (2010) Effects of liming on soil properties and plant performance of temperate mountainous grasslands. J Environ Manage 91:2066-2074. https://doi.org/10.1016/j. jenvman.2010.05.011

Nilsson SI, Andersson S, Valeur I, Persson T, Bergholm J, Wirén A (2001) Influence of dolomite lime on leaching and storage of $\mathrm{C}, \mathrm{N}$ and $\mathrm{S}$ in a Spodosol under Norway spruce (Picea abies (L.) Karst.). For Ecol Manage 146:55-73. https:// doi.org/10.1016/s0378-1127(00)00452-7

Nugroho RA, Röling WFM, Laverman AM, Verhoef HA (2007) Low nitrification rates in acid scots pine forest soils are due to $\mathrm{pH}$-related factors. Microb Ecol 53:89-97. https://doi.org/10.1007/s00248-006-9142-9

Paradelo R, Virto I, Chenu C (2015) Net effect of liming on soil organic carbon stocks: a review. Agric Ecosyst Environ 202:98-107. https://doi.org/10.1016/j. agee.2015.01.005

Persson T, Lundkvist H, Wirén A, Hyvönen R, Wessén B (1989) Effects of acidification and liming on carbon and nitrogen mineralization and soil organisms in mor humus. Water Air Soil Pollut 45:77-96

Persson T, Rudebeck A, Wirén A (1995) Pools and fluxes of carbon and nitrogen in 40-year-old forest liming experiments in Southern Sweden. Water Air Soil Pollut 85:901-906. https://doi.org/10.1007/BF00476944

Radziemska M, Bilgin A, Vaverková MD (2018) Application of mineral-based amendments for enhancing phytostabilization in Lolium perenne $\mathrm{L}$. cultivation. CLEAN-Soil Air Water 46:1600679. https://doi.org/10.1002/clen. 201600679

Scheiner D (1976) Determination of ammonia and Kjeldahl nitrogen by indophenol method. Water Res 10:31-36. https://doi.org/10.1016/00431354(76)90154-8

Shaaban M, Peng Q, Hu R, Wu Y, Lin S, Zhao J (2015) Dolomite application to acidic soils: a promising option for mitigating $\mathrm{N}_{2} \mathrm{O}$ emissions. Environ $\mathrm{Sci}$ Pollut Res 22:1-10. https://doi.org/10.1007/s11356-015-5238-4

Shaaban M et al (2017) Influence of ameliorating soil acidity with dolomite on the priming of soil $\mathrm{C}$ content and $\mathrm{CO}_{2}$ emission. Environ Sci Pollut Res 24: 9241-9250. https://doi.org/10.1007/s11356-017-8602-8

Tjv H, Lewis DC (1994) Influence of lime rate and particle size on soil pH and vegetative and seed yeilds of subterranean clover in the South East of South Australia. Aust J Exp Agric 34:367-371. https://doi.org/10.1071/EA9940367

$\mathrm{Wu} \mathrm{H}$ et al (2020) $\mathrm{CO}_{2}$ and $\mathrm{N}_{2} \mathrm{O}$ emissions in response to dolomite application are moisture dependent in an acidic paddy soil. J Soils Sediments 20:31363147. https://doi.org/10.1007/s11368-020-02652-w

Wu J, Joergensen RG, Pommerening B, Chaussod R, Brookes PC (1990) Measurement of soil microbial biomass $C$ by fumigation-extraction - an automated procedure. Soil Biol Biochem 22:1167-1169. https://doi.org/10. 1016/0038-0717(90)90046-3

Xiao D, Huang Y, Feng S, Ge Y, Zhang W, He X, Wang K (2018) Soil organic carbon mineralization with fresh organic substrate and inorganic carbon additions in a red soil is controlled by fungal diversity along a $\mathrm{pH}$ gradient. Geoderma 321:79-89. https://doi.org/10.1016/j.geoderma.2018.02.003
Zamanian K, Zarebanadkouki M, Kuzyakov Y (2018) Nitrogen fertilization raises $\mathrm{CO}_{2}$ efflux from inorganic carbon: a global assessment. Global Change Biol 24:2810-2817. https://doi.org/10.1111/gcb.14148

Zelles L, Stepper K, Zsolnay A (1990) The effect of lime on microbial activity in spruce (Picea abies L.) forests. Biol Fertil Soils 9:78-82. https://doi.org/10.1007/ BF00335866

\section{Publisher's Note}

Springer Nature remains neutral with regard to jurisdictional claims in published maps and institutional affiliations.

\section{Submit your manuscript to a SpringerOpen ${ }^{\circ}$ journal and benefit from:}

- Convenient online submission

- Rigorous peer review

- Open access: articles freely available online

- High visibility within the field

- Retaining the copyright to your article

Submit your next manuscript at $\boldsymbol{\nabla}$ springeropen.com 